Menoufia J. Agric. Biotechnology, Vol. 6 Feb. (2021): 1- 10 https://mjpam.journals.ekb.eg/

\title{
CHEMICAL CHARACTERIZATION OF CICHORIUM INTYBUS AND PORTULACA OLERACEA VARIETY GROWN IN EGYPT
}

\author{
S. A. El-Kodosy ${ }^{(1)}$, Sh. N. Draz ${ }^{(1)}$, Samia M. Khalil ${ }^{(1)}$ and Sh. R. Mosa ${ }^{(1,2)}$ \\ (1) Department of Agricultural Biochemistry, Faculty of Agriculture, Menoufia University, \\ Egypt \\ ${ }^{(2)}$ Ministry of Health and Population
}

Received: Jan. 26,2021

Accepted: Feb. 27,2021

\begin{abstract}
The present study was designed to determine the phytochemical constituents of Cichorium intybus and Portulaca oleracea and evaluate the antioxidant activity of their methanolic extract. It was found that Cichorium intybus and Portulaca oleracea contained total ash 6.08 and $7.12 \%$, crude lipid 0.63 and $0.54 \%$, crude protein 3.94 and $4.09 \%$, crude fiber 9.0 and $8.34 \%$, and total carbohydrates 80.33 and $79.91 \%$, respectively. Total phenolics in the Cichorium intybus were $172.9 \mathrm{mg} / \mathrm{g}$ while total flavonoids were $139.4 \mathrm{mg} / \mathrm{g}$. On the other hand, total phenolics and total flavonoids were 163.12 and $125.71 \mathrm{mg} / \mathrm{g}$ for Portulaca oleracea. HPLC analysis of Cichorium intybus and Portulaca oleracea showed the presence of 17 and 20 phenolic compounds, respectively. catechin, caffeic acid, and rutin acid were found in high levels in the Cichorium intybus and their amounts were $2926.598,1268.448$, and $509.948 \mathrm{mg} / 100 \mathrm{~g} \mathrm{dw}$ respectively. On the other hand, ferulic acid, caffeic acid, $p$-hydroxybenzoic acid and catechin were found to be in high levels in Portulaca oleracea and their amounts, which were $300.628,203.678$, 55.685 and $38.424 \mathrm{mg} / 100 \mathrm{~g}$ dry weight, respectively. The obtained results also showed that the methanolic extract of Egyptian Cichorium intybus has the highest antioxidant activity, this may be due to their high amount of total phenolics and flavonoids.
\end{abstract}

Key words: Cichorium intybus - Portulaca oleracea - Phenolics - Flavonoids antioxidant

\section{INTRODUCTION}

Human has a long history of consuming edible plants for food and survival and now still consumes a wide variety of wild and semi-domesticated food plants, domesticated crops, vegetables, fruits, and plant food supplements, as well as plants for medicinal uses (Ju, et al., 2013 and Lau et al., 2009). There is a promising future of medicinal plants as there are about half million plants around the world, and most of them are not investigated yet for their medical activities and their hidden potential of medical activities could be decisive in the treatment of present and future cases (Singh, 2015)

Cichorium intybus commonly known as

chicory belongs to the family

Asteraceae and is widely distributed in North Africa to south Asia for several 100 years (Jamshidzadeha et al., 2006). All parts of this plant possess great medicinal importance due to the presence of several medicinally important compounds such as alkaloids, inulin, sesquiterpene lactones, coumarins, vitamins, chlorophyll pigments, unsaturated sterols, and flavonoids. (Meehye and Shin, 1996). Leaves of chicory are good sources of phenols, vitamins ( $A$ and $C$ ) as well as potassium, calcium, and phosphorus (Mulabagal et al., 2009). Furthermore, chicory is rich cichoric acid and may stimulate the immune system as well as prevent inflammation and bacterial infections to a limited extent (Nayeemunnisa, 2009). Cichorium intybus 
has been traditionally used for the treatment of fever, diarrhea, jaundice, and gallstones. The studies on rats have shown that Cichorium intybus possesses anti-hepatotoxic and anti-diabetic activities (Katiyar, et al., 2015).

Portulaca oleracea (Portulacaceae family) is a well-known edible plant, which is widespread in temperate and tropical regions of the world. Many types of chemical compound are present in this plant, including unsaturated fatty acids, monoterpenoids, alkaloids, coumarins and flavonoids (Xiang et al., 2006).

Recently, the development of flavonoids in medical and food fields is becoming a hot research. Flavonoids and polysaccharides are the most abundant effective components in Portulaca oleracea. Seven kinds of flavonoids were found in Portulaca oleracea including quercetin, kaempferol, myricetin, apigenin, luteolin, genistein, and genistein. The extraction and separation of flavonoids with high biological activity and high content is very important for the medical and food industry. Therefore, it is of great significance to study the extraction and the determination technologies of flavonoids from Portulaca oleracea (Mahmood, et al., 2020).

\section{MATERIALS AND METHODS}

\section{Plant material}

Egyptian Cichorium intybus and Portulaca oleracea were collected from local field in Menoufia and the leaves of plants were identified by botanical members of the Department of Botany, Faculty of Agriculture, Menoufia University. The leaves were washed and air-dried for 24 hours, then dried at $50{ }^{\circ} \mathrm{C}$ to a constant weight. The dried samples were grinded into fine powder and kept in refrigerator for analysis.

\section{Determination of the chemical composition}

Ash content was determined by ignition of the dried sample at $550{ }^{\circ} \mathrm{C}$ until a constant weight according to the Association of Official Analytical Chemists, (AOAC, 2000). Crude fiber was determined according to AOAC, (2000). Total nitrogen was determined (dry basis) according to the modified micro-Kjeldahl method as described by AOAC., (2000). The crude protein contents were calculated using the conversion factor 6.25. Crude lipid was determined according to AOAC., (2000). The total carbohydrate determined by difference $=$ $100-$ (\% protein $+\%$ fat $+\%$ ash $+\%$ fiber).

\section{Preparation of plant extracts}

Dried powdered leaves, $(30 \mathrm{~g})$ from each plant were extracted by methanol $80 \%$ at room temperature for $24 \mathrm{~h}$. The resulting extracts were filtered using Whatman no. 1 filter paper and the residues were re-extracted by the same process until plant materials were exhausted. The collected filtrates were pooled and evaporated to dryness under reduced pressure to give a semisolid residue, which was then lyophilized to get powder and were stored at $4{ }^{\circ} \mathrm{C}$ until used.

\section{Determination of total phenolic compounds}

The phenolic level was determined by the modified Folin-Ciocalteu assay, as described by McDonald et al., (2001). One milliliter of extract and $5 \mathrm{~mL}$ of $10 \%$ FolinCiocalteu reagent were mixed, and then $4 \mathrm{~mL}$ of $2 \% \mathrm{Na}_{2} \mathrm{CO}_{3}$ was added. Reagent without extract (only absolute methanol) was used as a blank. After incubating all samples at room temperature for $60 \mathrm{~min}$, their absorbance was measured at 
$765 \mathrm{~nm}$ using spectrophotometer. The calibration curve for gallic acid (0$100 \mu \mathrm{g} / \mathrm{mL}$ ) was established to calculate the phenolic content. Total phenolics (TPC) were expressed as the $\mathrm{mg}$ gallic acid equivalent (GAE) per gram of extract.

\section{Determination of total flavonoid compounds}

The total flavonoid contents were determined using the method described by Dewanto, et al., (2002). Briefly, an aliquot $(250 \mu \mathrm{l})$ of each extract or a standard solution was mixed with $1.25 \mathrm{ml}$ of deionized water followed by $75 \mu \mathrm{l}$ of a 5\% NaNO2 solution. After $6 \mathrm{~min}, 150$ $\mu \mathrm{l}$ of a $10 \% \mathrm{AICl} 3.6 \mathrm{H} 2 \mathrm{O}$ solution were added to each mixture. After $5 \mathrm{~min}$, $0.5 \mathrm{ml}$ of $1 \mathrm{M} \mathrm{NaOH}$ was added, and the total volume was adjusted to 3.0 $\mathrm{ml}$ with deionized water. (+)-Catechin was used as a standard and the absorbance was measured at $510 \mathrm{~nm}$, using a spectrophotometer which was corrected using a blank. The results were expressed as $\mathrm{mg}$ of (+)-catechin equivalents (CE)/100 g dry matter.

\section{Quantitative identification of phenolics by HPLC}

A modified method of (Zuo, et al., 2002) analysis was carried out using HPLC (A shimazdzu IC 20 AT) equipped with a Luna TM $5 \mu \mathrm{m} \mathrm{C18,} 25 \mathrm{~cm} \times$ $4.6 \mathrm{~mm}$ i.d (Phenomenex, Torrance, CA, USA) column. S.PD-20 UV Visible detector was used. A gradient elution was carried out using the following solvent systems: Mobile phase A (acetonitrile / acetic acid/double distilled water- 9/2/89 v/v/v), Mobile phase B (acetonitrile/acetic acid/double distilled water - 80/2/18 v/v/v). The mobile phase composition for a binary gradient condition was started at $100 \%$ solvent $A$ for $10 \mathrm{~min}$ then over 15 minutes a linear gradient to $60 \%$ mobile phase $A, 32 \%$ mobile phase $B$ and held at this composition for $10 \mathrm{~min}$. The flow rate of the mobile phase was $1 \mathrm{ml} / \mathrm{min}$ and the temperature at the column performed at $35 \pm 0.5{ }^{\circ} \mathrm{C}$. The identification of individual components was carried out by comparing the retention times and UVabsorbance of unknown peaks with peaks obtained from the mixed known standard under the same condition.

\section{In vitro antioxidant activity reducing power assay}

A spectrophotometric method (Oyaizu 1986) was used for the measurement of reducing power. An aliquot $(2.5 \mathrm{ml})$ of each extract was mixed with $2.5 \mathrm{ml}$ of 200 $\mathrm{mmol} / \mathrm{l}$ sodium phosphate buffer (pH 6.6) and $2.5 \mathrm{ml}$ of $1 \%$ potassium ferricyanide. The mixture was incubated at $50{ }^{\circ} \mathrm{C}$ for 20 min. After adding $2.5 \mathrm{ml}$ of $10 \%$ trichloroacetic acid $(w / v)$, the mixture was centrifuged at $650 \mathrm{rpm}$ for $10 \mathrm{~min}$. The upper layer $(5 \mathrm{ml})$ was mixed with $5 \mathrm{ml}$ deionized water and $1 \mathrm{ml}$ of $0.1 \%$ of ferric chloride, and the absorbance was then measured at $700 \mathrm{~nm}$. Higher absorbance indicates higher reducing power. Vit.C was used as standard.

\section{RESULTS AND DISCUSSION.}

\section{Chemical composition of Cichorium intybus and Portulaca oleracea}

Table (1) indicate that Cichorium intybus contained total ash $6.08 \%$, crude lipid $0.63 \%$, crude protein $3.94 \%$, crude fiber $\mathbf{9 . 0} \%$, and total carbohydrates $\mathbf{8 0 . 3 3}$ $\%$. On the other hand, Portulaca oleracea contained total ash $7.12 \%$, crude lipid $0.54 \%$, crude protein $4.09 \%$, crude fiber $8.34 \%$, and total carbohydrates $79.91 \%$. The results are in accordance with those of Jancic, (2016), and Muhammad, et al., (2017) referring that Cichorium intybus chemical composition contains, total ash $6.9 \%$, crude lipids $0.44 \%$, crude protein 
$3.91 \%$, crude fiber $8.88 \%$ and total carbohydrates $80.48 \%$. while Ifeoma, et al., (2017) reported that Cichorium intybus had chemical composition of total ash $10.91 \%$, crude lipids $3.68 \%$, crude protein $14.7 \%$, crude fiber $16.7 \%$ and total carbohydrates $70.7 \%$.

Mastud, et al., (2018) showed that the Portulaca oleracea powder was a good source of crude fiber $(4.5 \pm 0.01 \%)$ and protein $(16.38 \pm 0.05 \%)$ and added that Portulaca oleracea contained $18.20 \pm 0.50 \%$ ash, $2.33 \pm 0.70 \%$ fat, and $58.89 \%$ carbohydrate, while El-Hadidy, (2014) and Obied et al., (2016) showed that Portulaca oleracea contained 17.50$29.04 \%$ protein, $5.00-12.00 \%$ crude fibers, $17.80-23.01 \%$ ash.

2. Total phenolic compounds and total flavonoids of Cichorium intybus and Portulaca oleracea extract.

Plant polyphenols are a major group of compounds acting as primary antioxidants or free radical scavengers. Therefore, it was reasonable to determine the total phenolic and flavonoid contents in the plant extracts. The results obtained shown in Table (2) indicates that the total phenolics in the Cichorium intybus were $172.9 \mathrm{mg} / \mathrm{g}$ GAE equivalent, while total flavonoids were $139.4 \mathrm{mg} / \mathrm{g}$ catechin equivalent. On the other hand, total phenolics and total flavonoids were $163.12 \mathrm{mg} / \mathrm{g}$ and $125.71 \mathrm{mg} / \mathrm{g}$ for Portulaca oleracea.

These data agree with Nasir et al., (2012) who reported that total phenolics in the Cichorium intybus extract were 285 $\mathrm{mg} / \mathrm{g}$ while total flavonoids were 150 $\mathrm{mg} / \mathrm{g}$. On the other hand, Mahmood Habibian et al., (2020) reported that total phenolics in the Portulaca oleracea extract was $142 \mathrm{mg} / \mathrm{g}$ while total flavonoids were $81.2 \mathrm{mg} / \mathrm{g}$.

\section{Quantitative analysis of phenolic compounds in Cichorium intybus and Portulaca oleracea by HPLC}

Polyphenolic compounds in Cichorium intybus and Portulaca oleracea were analyzed by High Performance Liquid Chromatography (HPLC), and the concentrations of all tested phenolic compounds were given in Table (3).

Table (1): The chemical composition of Cichorium intybus and Portulaca oleracea (W/W \%) on dry weight basis.

\begin{tabular}{|l|c|c|}
\hline \multicolumn{1}{|c|}{ Plants name } & Cichorium intybus & Portulaca oleracea \\
\hline Ash & 6.08 & 7.12 \\
\hline crude lipid & 0.63 & 0.54 \\
\hline Total Protein & 3.94 & 4.09 \\
\hline Crude Fiber & 9.0 & 8.34 \\
\hline Total carbohydrate & 80.33 & 79.91 \\
\hline
\end{tabular}

Table (2): Total phenolic and total flavonoids contents of Cichorium intybus and Portulaca oleracea.

\begin{tabular}{|c|c|c|}
\hline Plants & $\begin{array}{c}\text { Total phenolics } \\
(\mathrm{mg} / \mathrm{g}) \text { dry weight }\end{array}$ & $\begin{array}{c}\text { Total flavonoids } \\
(\mathrm{mg} / \mathrm{g}) \text { dry weight }\end{array}$ \\
\hline Cichorium intybus & 172.9 & 139.4 \\
\hline Portulaca oleracea & 163.12 & 125.71 \\
\hline
\end{tabular}


Table (3): HPLC analysis of phenolic compounds in Cichorium intybus and Portulaca oleracea.

\begin{tabular}{|c|c|c|c|}
\hline No & Phenolic compounds & $\begin{array}{c}\text { Cichorium intybus } \\
\text { (mg / 100g dry weight) }\end{array}$ & $\begin{array}{c}\text { Portulaca oleracea } \\
\text { (mg / 100g dry weight) }\end{array}$ \\
\hline 1 & Gallic acid & 21.407 & 27.633 \\
\hline 2 & Protocatechuic & 47.778 & 15.895 \\
\hline 3 & p-hydroxybenzoic acid & 7.462 & 55.685 \\
\hline 4 & Gentisic acid & 18.890 & 2.610 \\
\hline 5 & Catechin & 2926.598 & 38.424 \\
\hline 6 & Chlorogenic acid & 1.403 & 1.578 \\
\hline 7 & Caffeic acid & 1268.448 & 203.672 \\
\hline 8 & Syringic acid & 2.062 & 14.891 \\
\hline 9 & Vanillic acid & 17.228 & 20.424 \\
\hline 10 & Scopoletin & 0.000 & 0.000 \\
\hline 11 & Ferulic acid & 90.918 & 300.628 \\
\hline 12 & Sinapic acid & 9.857 & 27.839 \\
\hline 13 & p-counmaric acid & 0.000 & 16.887 \\
\hline 14 & Rutin & 509.948 & 24.205 \\
\hline 15 & Naringenin & 0.000 & 6.732 \\
\hline 16 & Apigenin-7-glucoside & 27.697 & 13.576 \\
\hline 17 & Rosmarinic acid & 3.469 & 0.000 \\
\hline 18 & Cinnamic acid & 2.205 & 0.501 \\
\hline 19 & Luteolin & 0.605 & 5.296 \\
\hline 20 & Apigenin & 0.000 & 6.095 \\
\hline 21 & Kaempferol & 0.000 & 0.906 \\
\hline 22 & Chrysin & 10.559 & 1.882 \\
\hline & & & \\
\hline
\end{tabular}

HPLC analysis for the phenolic compounds showed the presence of 17 compounds which were varied in their amounts. It was observed that catechin, caffeic acid, and rutin acid were found in high levels and their amounts were 2926.598, 1268.448, and $509.948(\mathrm{mg} / 100 \mathrm{~g}$ dw) respectively. While ferulic, (90.918) protocatechuic (47.778), apigenin-7glucoside (27.697), gallic acid (21.407), gentisic acid (18.890) and vanillic acid (17.228), were found to be in moderate amounts.

Chrysin (in $\mathrm{mg} / \mathbf{1 0 0 g ~ d w ) ~ ( 1 0 . 5 5 9 ) , ~}$ sinapic acid (9.857), phydroxybenzoic acid (7.462), rosmarinic acid (3.469), cinnamic acid (2.205), syringic acid (2.062), chlorogenic acid (1.403) and luteolin $(0.605)$ were found to be in low amounts in the methanolic Cichorium intybus extract. These data agree with those of Ifeoma, et al., (2017) and Rezvan, et al., (2018).

While the HPLC analysis of Portulaca oleracea for the phenolic compounds showed the presence of 20 compounds which were varied in their amounts. It was observed that ferulic acid, caffeic acid, phydroxybenzoic acid and catechin were found to be in high levels and their amounts which were $300.628,203.678$, 
55.685 and $38.424 \mathrm{mg} / 100 \mathrm{~g}$ dry weight respectively. While (in $\mathrm{mg} / \mathbf{1 0 0 g} \mathrm{dw}$ ) sinapic acid (27.939), gallic acid (27.633), rutin (24.205), vanillic acid (20.424), p-coumaric acid (16.887), protocatechuic (15.895), syringic acid (14.891) and apigenin-7-glucoside (13.576), were found in moderate amounts.

Naringenin (6.732), apigenin (6.095), luteolin (5.296), gentisic acid (2.610), chrysin (1.882), chlorogenic acid (1.578), kaempferol (0.906) and cinnamic acid (0.501) were found to be in low amounts (in $\mathrm{mg} / 100 \mathrm{~g} \mathrm{dw}$ ) in the methanolic Portulaca oleracea extract. These data agree with those of Erkan, et al., (2012) who reported that Portulaca oleracea is a rich source in phenolic compounds.

4. Reducing power activity for methanolic extract of Cichorium intybus and Portulaca oleracea

The methanolic leaf extract of Cichorium intybus and Portulaca oleracea have been reported to exhibit antioxidant activity both in vitro and in vivo in numerous studies due to their high amount of polyphenols such as, phenolics and flavonoids contents (Erkan 2012; Oliveira et al., 2009).

Fe (III) reduction is often used as an indicator of electron-donating activity, which is an important mechanism in phenolic antioxidant action (Nabavi et al., 2009). In this work, the presence of reductants (antioxidants) in the samples would result in the reduction of $\mathrm{Fe}^{+3}$ to $\mathrm{Fe}^{+2}$ by donating an electron.

Data in Fig (1) showed that the reducing power of Cichorium intybus extracts $(2.5 \%$ and $5 \%$ concentration), which were (94.3 and $219.3 \mathrm{mMol}$ Ascorbic Eq), while such parameter for $2.5 \%$ and $5 \%$ Portulaca oleracea extracts were (81.2 and 198.3 $\mathrm{mMol}$ Ascorbic Eq). These results are in accordance with those of Shad et al., 2013; Oliveira et al., 2009 who found that reducing power was $(72.37 \pm 7.26 \mathrm{mMol}$ Ascorbic Eq) for Cichorium intybus extract and it was $(70.3 \pm 5.7 \mathrm{mMol}$ Ascorbic Eq) for Portulaca oleracea extract.

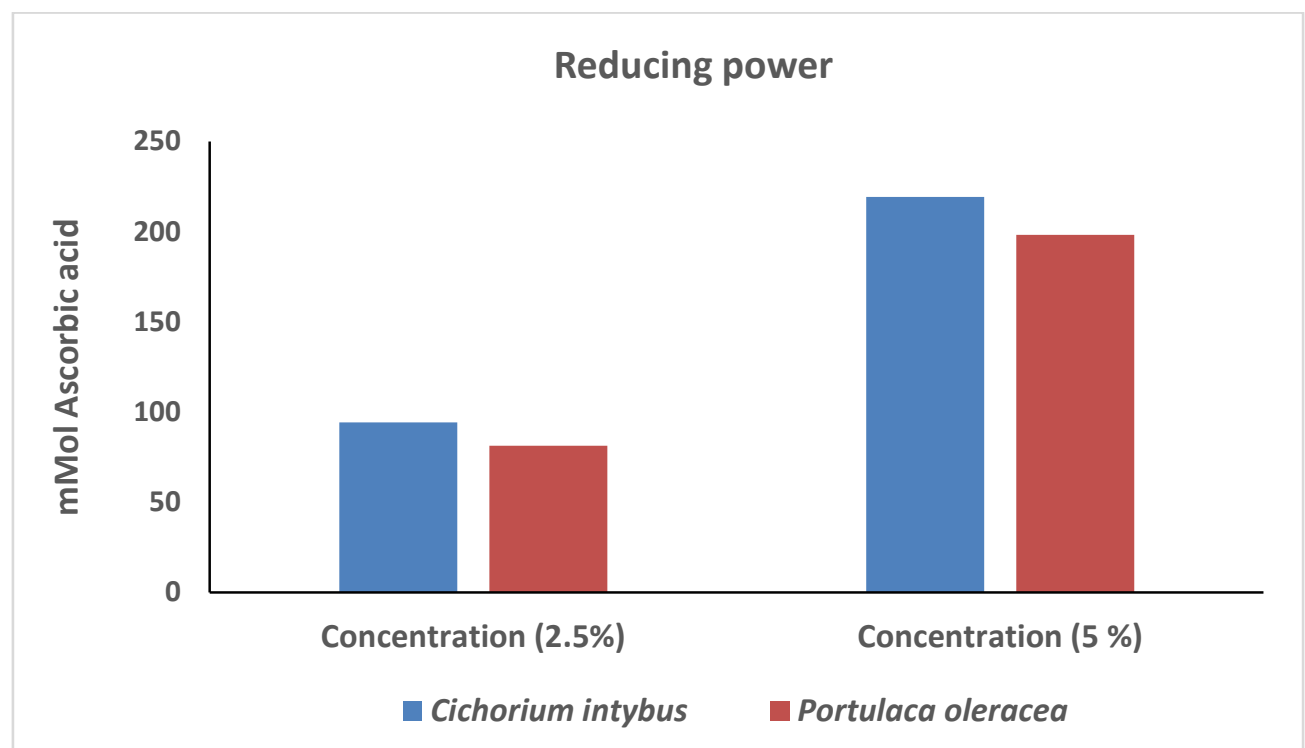

Fig (1) Reducing power activity for Cichorium intybus and Portulaca oleracea extracts 
The data also revealed that the reducing power of the leaf extract of Cichorium intybus was better than the methanolic leaf extract of Portulaca oleracea. In plants, reducing power assay has been considered as one of the most important indicators of antioxidant activity (Umamaheswari and, Chatterjee, 2008). The presence of reductants in the plant extract is commonly correlated with its reducing capabilities as reductants have shown the antioxidant action by terminating the radical chain reaction as they donate hydrogen atom in the reaction mixture. It has been observed that the total reduction ability of converting $\mathrm{Fe} 3+$ to $\mathrm{Fe} 2+$ in presence of both the extracts increased in a concentration dependent manner suggesting that both the extracts donates an electron in the reaction mixture which reacted with free radicals breaking down the chain reaction and transform them into much stable nonradical products.

\section{Conclusion}

The results of our study suggest that the methanolic leaf extracts of Cichorium intybus and Portulaca oleracea cultivated in Egypt are rich in polyphenolics and flavonoids compounds. The leaf extracts of these plants can be used as natural sources of antioxidants to prevent the progression of many diseases. The total phenolics and total flavonoids contents in the Cichorium intybus methanolic extract were higher than that in the Portulaca oleracea extract, and its methanolic extract was found to have marked in-vitro antioxidant activity due to their high amount of total phenolics and flavonoids, that justifies its use in traditional system of medicine in Egypt.

\section{REFERENCES}
A.O.A.C. Association of Official Analytical Chemists (2000). Official

Methods of Analysis, $17^{\text {th }}$ ed. of the Association of Official Analytical Chemistry, Washington, D.C, MSA.

Aebi, H. (1984). Catalase in vitro. In: Methods in Enzymology, Academic Press, New York, pp.479-500.

Becton, D. (1996). Unopette WBC/Platelet determination for manual methods. Rutherford, N.J.: Becton, Dickinson, and Company.

Brecher, G. and E.P. Cronkite (1950). Morphology and enumeration of human blood platelets. J Appl. Physiol.; 3:365.

Cannon, D.C., I. Olitzky and J.A. Inkpen (1974). Proteins. In: Clinical chemistry, principles and technics. 2-nd ed. RJ Henery. DC Cannon, JW Winkelman, editors, Harper and Row, New York, pp 407- 421.

Dacie, J.V. and S.M. Lewis (1975). Practical Haematology $5^{\text {th }}$ ed., Churchill Livingstone. London, Pp. 628. Dacie, J.V. and Lewis, S.M. (1984). Practical hematology, ghurch ill Livingston (ed,) selecto printing Co. Itd., New Yuork, Pp. 445.

Dewanto, V., X. Wu, K. K. Adom and R.H. Liu (2002). Thermal processing enhances the nutritional value of tomatoes by increasing total antioxidant activity. J Agric Food Chem. 50: 3010-3014.

Elgengaihi, S., A.T. Mossa, A.A. Refaie, D. Aboubaker (2016). Hepatoprotective Efficacy of Cichorium intybus $L$. Extract Against Carbon Tetrachlorideinduced Liver Damage in Rats. J Diet Suppl. 13(5):570-84.

Funk, V. A. and S. O. Fragman (2009). Systematics, Evolution, and Biogeography of Compositae . International Association for Plant Taxonomy. pp. 327-332.

Ifeoma, C.N., S. Karabo and C.A. Matthew (2017). Chemical Composition and Nutritive Benefits of Chicory 
(Cichorium intybus) as an Ideal Complementary and/or Alternative Livestock Feed Supplement the Scientific World Journal Volume, 11 pages.

Jamshidzadeha, A., J.M. Khoshnooda, Z. Dehghanib and H. Niknaha (2006). Hepatoprotective activity of Cichorium intybus $L$. leaves extract against carbon tetrachloride induced toxicity. Iranian J. Pharm. Res. 1, 41-46.

Jancic, D., V. Todorovic, Z. Basic and S. Sobajic (2016). Chemical composition and nutritive potential of Cichorium intybus $L$. leaves from Montenegro $\mathrm{J}$. Serb. Chem. Soc. 81 (10) 1141-1149.

Ju, J.; Zhuo, J.; Liu, B. and Long, C., (2013). Eating from the wild: diversity of wild edible plants used by Tibetans in Shangri-la region, Yunnan, China. Journal of Ethnobiology and Ethnomedicine volume 9, 1766-1769.

Katiyar, P., K. Amod, K. M. Arvind, K. D. Rakesh, K. Ajay, K. Rahul and K. G. Ajay (2015). Kasni (Cichorium Intybus L.) a propitious traditional medicinal herb. International Journal of Pharmacognosy Vol. 2(8): 368-380.

Khalid, A., S. Shahid, S. K. Ahmad, S. Kanwal, A. Yaqoob, Z. R. Ghulam and K. Rizwan (2018). Antioxidant activity and hepatoprotective effect of Cichorium intybus (Kasni) seed extract against carbon tetrachlorideinduced liver toxicity in rats Trop $J$ Pharm Res; 17(8): 1531-1538

Landue, S. and B.S. Everitt (2004). A Handbook of statistical Analyses using SPSS. -London: Chapman \&Hall/CRC press LLC, 2004. - $337 \mathrm{p}$.

Lau A.J.; Toh D. F.; Chua T. K.; Pang Y. K.; Woo S. O. and Koh H. L.,(2009). Antiplatelet and anticoagulant effects of Panax notoginseng: comparison of raw and steamed Panax notoginseng with Panax ginseng and Panax quinquefolium. $\mathrm{J}$ Ethnopharmacol; 125(3): 380-6.

Mahmood, H., G. Sadeghi and K. Ahmad (2020). Phytochemicals and Antioxidant Properties of Solvent Extracts from Purslane (Portulaca oleracea $L$.): A Preliminary Study Food Science and Engineering Volume 1 Issue 1 .

McDonald, S., D. Prenzler, M. Antolovich and K. Robards (2001). "Phenolic content and antioxidant activity of olive extracts," Food Chemistry, vol. 73, no. 1, pp. 73-84.

Meehye, K. and H.K. Shin (1996). The water-soluble extract of chicory reduces glucose uptake from the perfused jejunum in rats. J. Nutr. 126 (9): 2236-2242.

Moss, D.W., A.R. Henderson and J.F. Kachmar (1987). Enzymes in: Tietz NW, ed. Fundamentals of clinical chemistry. $3^{\text {rd }}$ ed. Philadelphia: WB Saunders; 346-421.

Muhammad, S., E. A. Mohamed, A. Mahmoud, A. A. Muhammad, A. Muhammad, A. M. Muhammad, N. Muhammad, C. Sun, S. Muhammad, M. Sayab and D. Kuldeep (2017). Chicory (Cichorium intybus) Herb: Chemical Composition, Pharmacology, Nutritional and Healthical Applications. Int. J. Pharmacol., 13 (4): 351-360.

Mulabagal, V., H. Wang, M. Ngouajio and M.G. Nair (2009). Characterization and quantification of health beneficial anthocyanins In leaf chicory (Cichorium intybus) varieties. Eur. Food Res. Technol. 230, 47-53.

Muriel, P. (2009). Role of free radicals in liver diseases. Hepatology international. volume3, lissue 4, pp 526-536.

Natt, M.P. and C.A. Herrick (1952). A new blood diluent for counting 
erythrocytes and leucocytes of the chicken. Poultry Science, 31, 735-738.

Nayeemunnisa, A. (2009). Alloxan diabetes-induced oxidative stress and impairment of oxidative defensesystem in rat brain: neuroprotective effects of Cichorium intybus. Int. J. Diabetes Metabol., 17, 105-109.

Nishikimi, M., N. Appaji and K. Yagi (1972). The occurrence of superoxide anion in the reaction of reduced phenazine methosulfate and molecular oxygen. Biochem. Biophys. Res. Commun., 46: 849-854.

Ohkawa, H., N. Ohishi and K. Yagi (1979). Assay for lipid peroxidation in animal tissues by thiobarituric acid reaction. Anal Biochem; 95: 351-358.

Oyaizu, M. (1986). Studies on product of browning reaction prepared from glucose amine. Jpn J Nutr. 07:307-15.

Repetto, M., J. Semprine and A. Boveris (2012). Lipid Peroxidation: Chemical Mechanism, Biological Implications and Analytical Determination, Lipid Peroxidation, Angel Catala, IntechOpen, DOI: 10.5772/45943.

Rezvan, N., H. Mahsa, A. Fariba, Azita Manshoori, Sh. Ali and K. Ali (2018). Maternal Administration of Cichorium intybus $L$. Extract Decreases the Plasma Total and Conjugated Bilirubin Level in Rat Neonates. Jundishapur $\mathbf{J}$ Nat Pharm Prod; 13(2).

Schutze, H. E. and J. F. Heremans (1966). Molecular Biology of Human Proteins, Elsevier publishing, Vol. I, Sec. III, ch. 3, p. 670.

Shaw, L. M., J. H. Strømme, J. L. London and L. Theodorsen (1983). International Federation of Clinical Chemistry. Scientific Committee, Analytical Section. Expert Panel on Enzymes. IFCC methods for measurement of enzymes. Clin Chim Acta, 135(3): 315F-338F.

Singh, R. (2015). Medicinal plants: A review. J. plant Sci.3:(1):50-55.

Smith, M.E. and D.G. Morton (2010). "Liver and Biliary System". The Digestive System. Elsevier. pp. 85-105

Tietz, N.W. (1990). Clinical guide to laboratory tests. 2nd ed. Philadelphia: WB Saunders.

Umamaheswari, M. and TK. Chatterjee (2008). In vitro antioxidant activities of the fractions of Coccinia grandis $L$. leaf extract. African Journal of Traditional, Complementary and Alternative Medicines; 5(1): 61-73.

Wang, Y., L. Zhijian, Z. Bing, W. Xiao and C. Mengzhen (2019). Chicory (Cichorium intybus L.) inhibits renal reabsorption by regulating expression of urate transporters in fructoseinduced hyperuricemia Journal of Traditional Chinese Medical Sciences Volume 6, Issue 1, Pages 84-94.

Xiang, L., D.M. Xing, W. Wang, R.F. Wang and L.J. Du (2006). Review on chemical constituents of Portulaca oleracea L. Asia-Pacific Traditional Medicine 7, 64- 68.

Young, D.S. (1990). Effects of drugs on clinical laboratory tests. Third edition 4th Ed. Washington, DC; AACC Press: 3:6 -12.

Young, D.S. (2001). Effects of disease on clinical lab. tests. 4th ed AACC American Association for Clinical Chemistry. Zargary, A (1989): The medicinal plants.5th. Ed. Tehran university publication, Tehran. 312314.

Zuo, Y., H. Chen and Y. Deng (2002). Simultaneous Determination of Catechins Caffeine and Gallic acids in Green, Oolong, Black and Pu-err Teas using HPLC with a Photodiode Array Detector. Talanta, 57: 307-316. 
الخصائص الكيميائية لنباتات الشكوريا والرجله المزروعة في مصر

سمير عبد الله القدوسي(1)، شعبان نجم دراز (1)، سامية محمد خليل(1)، شاهين رشوان(1، 2) ،

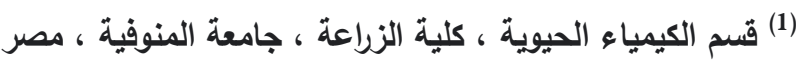
(2) مستثفى معهد ناصر للبحوث والعلاج

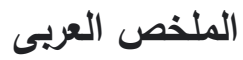

صممت الاراسة الحالية لتحديد المكونات الكيميائية لنباتى الثكوريا و الرجلة وتقييم النثاط المضاد للأكسدة

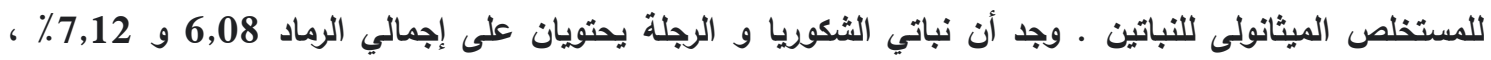

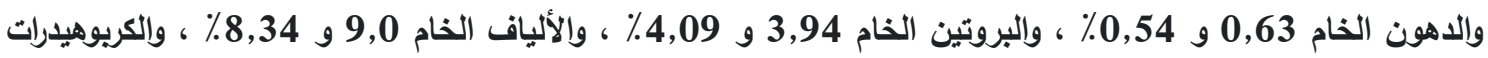

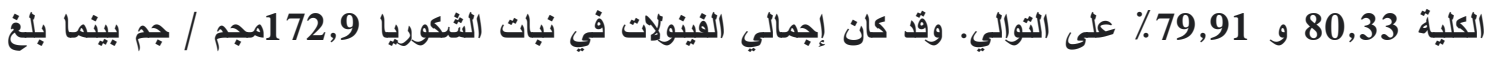
إجمالي مركبات الفلافونويد 139.4 مجم / جم ، من ناحية أخرى كان إجمالي الفينولات وإجمالي مركبات الفلافونويد 163,12 مجم / جم و 125,71 مجم / جم في نبات الرجلة ـ أظهر التحليل الكروماتوجرفى لنباتى الثكوريا و الرجلة الثمانة

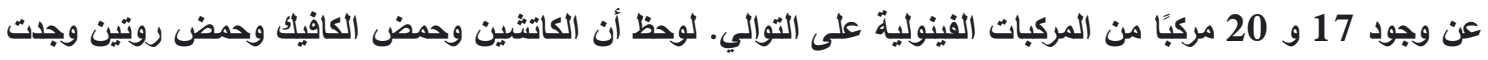

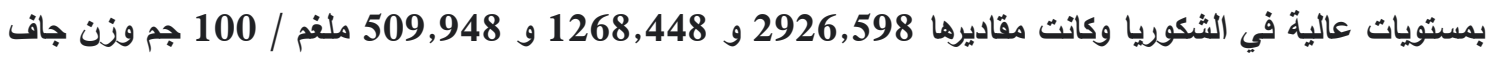

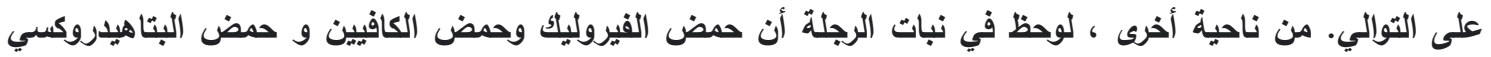
بنزويك و الكاتثين كانت بمستويات عالية وكاتت مقاديرها 300,628 و 203,678 و

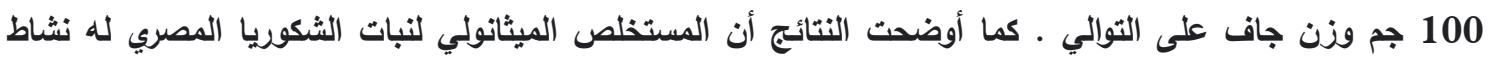
مضاد للأكسدة عال، وقث يرجع ذلك إلى ارتفاع كمية الفينولات والفلافونويد. 